\title{
Diachronic Linguosynergetics: Focus on Simple and Derived Words
}

\author{
T. I. Dombrovan
}

English Grammar Department, Odessa I.I. Mechnikov National University, Ukraine

Corresponding author. E-mail: dombrovan@gcn.ua

Paper received 19.11.17; Revised 22.11.17; Accepted for publication 24.11.17.

https://doi.org/10.31174/SEND-HS2017-146V24-04

\begin{abstract}
The article discusses the structure of English words through a novel methodological angle which is synergetics. The methodological peculiarity of synergetics consists in the study of the evolutionary processes as a multi-stage self-regulation of a certain structural unity. Language is defined as a synergetic system, due to its openness, non-linearity, dynamism and fractal organisation. The linguistic subsystem of affixes that help to create new words should be regarded as a synergetic system, too, because it is subject to changes under the constant influence of external factors.
\end{abstract}

Keywords: synergetics, diachronic synergetics, language, a synergetic system, structure of words, the English language.

Introduction. The term 'synergetics' (from Greek 'coherent action') was coined by the German physicist Hermann Haken in the mid-1970s to name a science of complexity, dealing with principles of emergence, self-organisation and self-regulation of complex systems of various ontologies either man-made (artificial) or natural (self-organised).

Synergetics is regarded as a new stage in the development of the theory of systems with special emphasis on issues of evolution and phase shifts. The methodological peculiarity of synergetics consists in the study of the development processes as a multi-stage self-regulation of a certain structural unity. Synergetics has changed our world outlook by representing reality as open, ever-changing, non-linear, and infinite in the choice of alternatives of further development.

The methodology and conceptual network of synergetics can be employed in various spheres of scientific activity studying complex evolving systems, including human language.

The aim of the paper is to consider dynamism within the morphological structure of English words through the synergetic conceptual net. This calls for solving a number of tasks, namely: to define language as a synergetic system; to outline main tasks and vectors of scientific research within linguistic synergetics; to state the aim of diachronic linguosynergetics; to study the morphology of English words in the Old and Middle periods.

Discussion. A new approach to the study of complex open dynamic systems facilitates the introduction of new terminology. Key concepts of synergetics include a closed/open system, linearity/non-linearity, self-organisation, dissipation, order (control) parameters, fluctuations, bifurcations, stability (equilibrium) / instability, an attractor, a fractal, coherence and some others. Application of these notions to linguistic investigations has proved their validity and has allowed a novel perception of language as a self-regulated system.

The use of methodology and conceptual network of synergetics in the study of language brought about emergence of linguistic synergetics, also known as linguosynergetics.

Linguistic synergetics, which appeared at the close of the $20^{\text {th }}$ century, is a new stage in the investigation of language as an open, non-linear, dynamic system. The system's equilibria have been fully described within 'conventional' linguistics and its branches, while linguistic synergetics aims at the study of language at the change point, in the situations of restructuring and reorganisation caused by external influence.
Human language can be defined as a complex synergetic megasystem, which changes and develops in compliance with the universal principles of the complex system's behaviour revealed within the theory of synergetics. Synergetic systems are multi-component systems characterised by the complex behaviour of their parts and subsystems. From the perspective of the synergetic approach, human language is considered an open, dynamic, non-linear, self-organising system with all its hierarchical subsystems and elements coherently interconnected and controlled by governing parameters.

Language is known to be undergoing changes all the time; however, its various levels and subsystems are changing at a different rate. In spite of any alterations, language remains capable of performing its communicative functions in society not only among contemporaries, but also between generations.

Diachronic synergetics, first advanced in [Dombrovan 2012], deals with principles of language change and development. It is closely connected with historical linguistics. It aims at understanding the main stages of language evolution, including the emergence of language, the peculiarities of its non-linear development (gradual at times and sometimes fast), the coherent behaviour of its components and subsystems, the impact of external factors (including language contacts) on language structure, etc. A wide range of data has been presented as part of fascinating research into pidgins and creoles.

Investigation of language within the synergetic paradigm is imperative and is determined by features of language as an open self-organised synergetic system. Here, subdivision into synchronic synergetics and diachronic synergetics is highly conditional and merely theoretical, for a language system is permanently dynamic.

Distinguishing between synchronic and diachronic approaches means temporarily singling out the study of the language system in its dynamic equilibrium (synchrony) and in the phase-transition state, causing qualitative changes in the language's organisation and functioning (diachrony). Synchronic and diachronic approaches represent the two indispensible, complementary and interrelated planes of the research process.

Diachronic synergetics is sure to offer a new angle on the dynamic language system, while implementing new principles of the synergetic analysis and synthesis will make it possible to contribute to the theory of complex systems evolution. The main idea of diachronic synergetics lies within 
the multi-directional, non-linear evolution of a language system. The concept of non-linearity is the most essential for language development.

In what follows, we will focus on the morphological composition of words during the Old and Middle English periods.

According to their morphological composition, words are traditionally divided into simple, derived and compound. Simple words contain only one root morpheme plus/minus an ending. Derived words have a prefix or a suffix, or both, attached to the root morpheme. Compound words consist of two or more stems written solid or hyphenated. In Old English there existed the three main morphological classes of words. The object of analysis in the present paper is simple and derived words. Let's start with simple ones.

Endings of Old English nouns and adjectives marked the grammatical categories of number, case and gender. Old English verb terminations marked the grammatical categories of person, number, tense and mood. However, many Old English simple words seem to have been derived ones in the earlier period. Thus, for example, in the Old English noun stān «stone» the component $-n\left(<*_{-} n a\right)$ had been a wordforming suffix widely used in Indo-European languages. This suffix and the root morpheme grew together into one, giving the adjectives stōnen, stōeni3 «stony», and the verb stōenan «to throw stones» [Smirnitsky 1998:160]. Put another way, in the course of time the suffix can lose its status, then become dim, and finally merge with the root morpheme, which results in a certain shift of boundaries between the components of a word. The suffix turns into an element of the root morpheme. The morphemic boundary (also called 'a morphemic seam') disappears, and a new root morpheme is formed.

Another example of a change in the grammatical status of a morpheme is illustrated by transition of the suffix *-na into the ending -n/-an (sēon «to see», têon «to tow»; bindan «to bind», helpan «to help»). Originally, this suffix had been used to form nouns of neuter gender indicating an action; later on from them, there developed infinitives which entered the system of verb forms [Smirnitsky 1998:160]. That is to say, a word-formation suffix changed its status and became a termination of one of the verb forms. This allows philologists to refer the Old English noun $\operatorname{cyr}(r)$ «a turn» (with all its paradigm forms) and the Old English verb cyrran ('to turn') to the group of simple words.

Research into the word-structure in Old Germanic languages reveals a tendency towards root augmentation. It is believed that the primary structure of the root was CV (consonant + vowel), and the primary structure of a word was CVCVCV, where the syllable boundaries coincided with those of the morpheme. In the course of time, the appearance of grammatical categories and the necessity of their explication with the help of linguistic means brought about functional restructuring of certain components of a word, which finally resulted in the appearance of suffixes and inflections. Due to the formation of two types of declension (a consonant type and a vowel type), the middle syllable split into a consonant and a vowel, the latter (as a rule) was subject to reduction, and the former subsequently entered the root morpheme. As a result, the morphemic structure of a word modified into CVC-V-CV, where boundaries of morphemes and those of syllables did not coincide. This structure is thought to have given the following variants $\mathrm{CVC}-\mathrm{VC}, \mathrm{CVCC}, \mathrm{CVC}$, CV [Taranets 2009:135]
Generally, what today seems a simple word may not have been so in the past. A suffix can merge with the root, which causes the boundary shift due to the attraction of the suffix. Alternatively, a suffix can turn into an inflection that tends to get levelled and/or reduced and then lost, which was amply demonstrated by the historical development of the English language. Obviously, the inner boundaries of a word-form are not rigid but dynamic. The word structure has a deep fractal configuration revealing the complexity of the simple.

The next group to be considered includes derived words, i.e. the ones containing affixes (prefixes and/or suffixes).

In Old English, suffixation as a pattern of word-formation was widely used. There existed noun-forming suffixes, adjective-forming suffixes, numeral-forming suffixes, adverbforming suffixes, and verb-forming ones. Researchers have noted that word-formation patterns differed within Old English dialects. Thus, to form nouns of the feminine gender indicating an agent of the action, the Angles had the suffix ic Ze (as in huntic 3e "a hunting woman"), while the Saxons used the suffix -ester (as in huntigestre). The same is true of the adjective-forming suffixes $-i 3$ and -welle that were only found in Northumbrian manuscripts [see: Kastovsky 2005: 350]:

drunceni3 'drunk' < drunken 'drunk',

Piostri3/Pystri3 'obscure, dark' < Peostor 'dark',

lifwelle 'living', hundwelle 'a hundredfold', rumwelle 'spacious'.

Suffixes of Old English classes of speech were Germanic in origin. Borrowing suffixes from Latin and French took place in the Middle Ages and later, together with borrowing new words. Sometimes, a part of a loan-word began to be perceived as a suffix and, as such, started its own 'life'. A good example is the element -ment that entered the Middle English language together with the lexemes government, agreement and was interpreted as a suffix, which, in its turn, made it possible to join it to originally English roots, thus forming new words, e.g. fulfilment, bereavement, amazement, bewilderment, etc.

Analysis of linguistic facts has made it possible to produce inventories of suffixes of nouns, adjectives and verbs in a historical retrospective.

The following table lists changes in the dynamic subsystem of noun-forming suffixes through the Old English period to Modern English.

As is seen in Table 1, many of the Old English nounforming suffixes survived in Modern English, though the degree of their productivity has changed. Thus, the suffix - $\mathbf{-}$, modified into -th/-t, was no doubt highly productive in Old English which is shown in the great number of nouns containing it, as in: growth, length, width, health, truth, wealth, frost, flight, height etc. Nowadays, however, it is not used to form new words, and that is why it is not included in the list of productive suffixes any more.

A good example of mobility of inner (i.e. morphemic) boundaries of a word is the Modern English friend. Today it possesses the noun paradigm and is referred to simple nouns, but in the past it was not such. The Old English suffix -nd originated from the suffix of participle I -ende. Having been attracted by the root morpheme, it lost its status of a suffix and became a part of the base of the word. Nowadays the noun friend is seen as a simple noun but not as participle I, though it derived from the Old English verb frēogan, Goth. frijōn, OSax. friohan<Germ. *frijojan.

Similarly, the Modern English noun fiend comes from 
participle I fijand from Old English verb fêon (OHG. fièn, of a participle lost its status and joined the root morpheme. OIcel fjā , Goth. fijan<Germ. *fijójan-). Later on, the suffix

Table 1. Changes in the subsystem of noun-forming suffixes

\begin{tabular}{|c|c|c|c|c|}
\hline \multicolumn{2}{|c|}{ Old English } & \multicolumn{2}{|c|}{ Middle English } & \multirow{2}{*}{$\begin{array}{c}\text { Modern English } \\
\text { suffix }\end{array}$} \\
\hline suffix & examples & suffix & examples & \\
\hline $\begin{array}{c}\text {-ere (profession, } \\
\text { male) }\end{array}$ & $\begin{array}{l}\text { fiscere } \\
\text { writere }\end{array}$ & -ere & writere & $\begin{array}{c}\text {-er } \\
\text { writer }\end{array}$ \\
\hline $\begin{array}{c}\text {-estre (profession, } \\
\text { female) }\end{array}$ & $\begin{array}{c}\text { spinnestre } \\
\text { baecestre witegestre }\end{array}$ & -stere & tappestere & $\begin{array}{l}\text {-ster } \\
\text { tapster } \\
\text { spinster }\end{array}$ \\
\hline $\begin{array}{l}\text {-nd <-ende } \\
\text { (agent, male) }\end{array}$ & $\begin{array}{l}\text { frēond, fēond } \\
\text { dēmend }\end{array}$ & - & & - \\
\hline $\begin{array}{c}\text {-ing (descendant, } \\
\text { male) }\end{array}$ & $\begin{array}{c}\text { cedeling } \\
\text { cyning Adeiwulfing }\end{array}$ & -ing $(e)$ & & - \\
\hline $\begin{array}{c}\text {-ling } \\
\text { (diminutive, male) }\end{array}$ & \begin{tabular}{|c|} 
lötling \\
gōsling \\
\end{tabular} & -(l)ing & & $\begin{array}{c}\text {-ing/-ling } \\
\text { darling, duckling }\end{array}$ \\
\hline $\begin{array}{c}\text {-en }(<- \text { in }) \\
\text { (animate, female) }\end{array}$ & $\begin{array}{l}\text { gyden } \\
\text { fyxen }\end{array}$ & -en & & $\begin{array}{c}\text {-en } \\
\text { vixen }\end{array}$ \\
\hline $\begin{array}{c}\text {-nis/-nes } \\
\text { (abstract nouns, } \\
\text { from adjectives) }\end{array}$ & $\begin{array}{l}\text { Gōdnis } \\
\text { Prēnes } \\
\text { hēahnes }\end{array}$ & -nesse & $\begin{array}{l}\text { holynesse } \\
\text { highness }\end{array}$ & $\begin{array}{l}\text {-ness } \\
\text { goodness }\end{array}$ \\
\hline $\begin{array}{c}-\mathbf{u} /-\partial \mathbf{u} \\
\text { (abstract nouns, } \\
\text { from adjectives) }\end{array}$ & $\begin{array}{c}\text { long }+-u=\text { lenga } u \\
\text { strong }+-u=\text { strengu }\end{array}$ & -the & lengthe & length, strength \\
\hline $\begin{array}{c}\mathbf{- \mathbf { P }} / \mathbf{- u \mathbf { W }} / \mathbf{- o \mathbf { P }} \\
\text { (abstract nouns, } \\
\text { from adjectives) }\end{array}$ & $\begin{array}{c}\text { trēowP } \\
\text { geonguP } \\
\text { fiscoP } \\
\text { huntoP }\end{array}$ & -the & $\begin{array}{c}\text { helthe } \\
\text { (> health), } \\
\text { welthe } \\
\text { (> wealth) }\end{array}$ & $\begin{array}{c}\text {-th } \\
\text { health }\end{array}$ \\
\hline $\begin{array}{c}\text {-ung/-ing } \\
\text { (nouns, feminine, } \\
\text { from verbs) }\end{array}$ & $\begin{array}{c}\text { leornung, learning } \\
\text { róeding }\end{array}$ & $\begin{array}{l}\text {-ing, } \\
- \text { yng }\end{array}$ & $\begin{array}{l}\text { meeting } \\
\text { lernyng }\end{array}$ & $\begin{array}{l}\text {-ing } \\
\text { meeting }\end{array}$ \\
\hline $\begin{array}{c}\mathbf{- d o ̄ m} \\
\text { (abstract nouns) } \\
\end{array}$ & $\begin{array}{l}\text { wīsdōm } \\
\text { frēodōm }\end{array}$ & $\begin{array}{l}\text {-doom, } \\
\text {-dom }\end{array}$ & freedom & $\begin{array}{c}\text {-dom } \\
\text { freedom }\end{array}$ \\
\hline $\begin{array}{c}\text {-hād } \\
\text { (abstract nouns) }\end{array}$ & cildhād & $\begin{array}{l}\text {-had, } \\
\text {-hood }\end{array}$ & childhood & $\begin{array}{c}\text {-hood } \\
\text { childhood }\end{array}$ \\
\hline $\begin{array}{c}\text {-lāc } \\
\text { (abstract nouns) }\end{array}$ & $\begin{array}{l}\text { wedlāc } \\
\text { scīnlāc }\end{array}$ & -lock & wedlock & $\begin{array}{c}- \\
\text { wedlock }\end{array}$ \\
\hline $\begin{array}{c}\text {-rāeden } \\
\text { (abstract nouns) }\end{array}$ & $\begin{array}{l}\text { frēondróéden } \\
\text { sibbróden } \\
\text { mannróden }\end{array}$ & -red & $\begin{array}{l}\text { hatred, } \\
\text { kindred }\end{array}$ & $\begin{array}{l}- \\
\text { hatred, } \\
\text { kindred }\end{array}$ \\
\hline $\begin{array}{c}\text {-scipe } \\
\text { (abstract nouns) }\end{array}$ & $\begin{array}{l}\text { Frēondscipe } \\
\text { folc-scipe }\end{array}$ & -ship & hardship & $\begin{array}{c}\text {-ship } \\
\text { friendship }\end{array}$ \\
\hline & & $\begin{array}{l}\text {-ance/ } \\
\text {-ence }\end{array}$ & $\begin{array}{l}\text { entrance, } \\
\text { experience }\end{array}$ & $\begin{array}{l}\text {-ance/ } \\
\text {-ence }\end{array}$ \\
\hline & & -ment & $\begin{array}{l}\text { treatment, } \\
\text { agreement }\end{array}$ & -ment \\
\hline & & -ess & princess & -ess \\
\hline & & -et/-let & coronet,leaflet & -et/-let \\
\hline & & -age & $\begin{array}{c}\text { courage, } \\
\text { mile- } \\
\text { age,marriage }\end{array}$ & -age \\
\hline & & -ard & $\begin{array}{l}\text { coward } \\
\text { bastard }\end{array}$ & -ard \\
\hline & & -al & refusal & -al \\
\hline & & -é> ee & lessee & -ee \\
\hline & & -tee $>$-ty & $\begin{array}{c}\text { posteritee } \\
\text { (>posterity), } \\
\text { countee } \\
\text { (>county) }\end{array}$ & $-\mathbf{t y}$ \\
\hline & & -(i)oun & $\begin{array}{c}\text { possessioun } \\
\text { (>possession), } \\
\text { porcioun } \\
(>\text { portion })\end{array}$ & -ion \\
\hline & & -our & $\begin{array}{c}\text { instructour } \\
\text { (>instructor) }\end{array}$ & -or \\
\hline & & -ry & fishery, bakery & -ry \\
\hline
\end{tabular}

In the system of Old English suffixes there were some suffixes that at the time were in a transition stage - from an independent word to a bound affix. To such suffixes refers the suffix of abstract nouns -scipe (<*sciepe), originating 
from Old English noun (of male gender) scipe (<*skepi $<*$ skapiz), meaning 'state, position, characteristics', etymologically connected with Old English verb scieppan 'to create'.

The suffix -dom comes from the corresponding Old English noun meaning 'state, statement, trial' (hence, Modern English doom). Another example is the suffix -hād that originates from the Old English noun $h \bar{a} d$ 'state, position, rank' (from Germ. *haiđ- 'rank, state'). In Old English, the trajectory of development of these elements changed: at first, they were independent words and free components of compounds; later, their semantics within a compound gradually weakened, which led to the subsequent transformation of the given words into word-formation affixes.

On the whole, a classification of Old English nouns according to their morphological structure (i.e. into simple, derived and compound) represents quite a problem and is highly approximate, for it reveals the following transformational algorithm: "a word form $\rightarrow$ a suffix $\rightarrow$ an inflection".

Modern English adjective-forming suffixes are mostly Germanic in origin (see Table 2 below). While the system of noun-forming suffixes was enriched by a dozen suffixes of French and Latin origin, the system of adjective-forming suffixes appeared to be more stable. Suffixes of Old English adjectives have retained their functions; in Middle English, they were not ousted by the newly borrowed suffixes which only widened word-formation potency of the Middle English language.

Among adjective-forming suffixes are those etymologically coming from other adjectives or nouns. For instance, the Old English suffix -full originates from Old English full < Germ. *fullaz (<*fulnaz); and the Old English suffix -lic comes from Old English licc, lice 'body, form, image'. It developed into -lice and began to function as an adverbforming suffix, e.g.

We habbad nu Zesced sceortlice on EnZlisc pis halize godspell... - We have briefly (shortly) given the explanation of this holy gospel into English... [YCOE: Ælfric's Homilies Supplemental, 8:50.1194].

Obviously, in the Old English period, the reinterpretation of a compound word as a derived word took place, which changed the grammatical status of the second component from a lexeme to a suffix. Moreover, the reduction and the subsequent loss of a vowel brought about the change -l $\breve{c}>-l c$ in the pronouns hwilc, hwelc 'which' and swilc, swelc 'such', as well as in $\bar{x} l c$ 'each'.

Table 2. Changes in the subsystem of adjective-forming suffixes

\begin{tabular}{|c|c|c|c|c|c|}
\hline \multicolumn{2}{|c|}{ Old English } & \multicolumn{2}{|c|}{ Middle English } & \multicolumn{2}{|c|}{ Modern English } \\
\hline suffix & examples & suffix & examples & suffix & examples \\
\hline -ede & hocede & -ed(e) & naked & -ed & naked, hooked \\
\hline$-i 3$ & $\begin{array}{l}\text { hāli3, misti3 } \\
\text { isi3, bysi3 }\end{array}$ & $-\mathbf{y}$ & $\begin{array}{l}\text { hali,holy;misty, } \\
\text { busy,wery, gilty }\end{array}$ & $-\mathbf{y}$ & $\begin{array}{l}\text { holy, misty, icy, busy, } \\
\text { weary, guilty }\end{array}$ \\
\hline -en & gylden, wyllen & -en & gulden, gilden & -en & golden, woollen \\
\hline -isc & $\begin{array}{c}\text { Englisc } \\
\text { Frencisc }\end{array}$ & $\begin{array}{l}\text {-iss, } \\
\text {-ish }\end{array}$ & Englissh & -ish & $\begin{array}{l}\text { English, } \\
\text { Spanish }\end{array}$ \\
\hline -sum & $\begin{array}{l}\text { langsum } \\
\text { hīersum }\end{array}$ & $-\operatorname{som}(e)$ & hoolsom & -some & $\begin{array}{c}\text { wholesome, } \\
\text { tiresome }\end{array}$ \\
\hline $\begin{array}{c}\text {-feald } \\
\text { (<fealdan) }\end{array}$ & $\begin{array}{c}\text { Drīefeald } \\
\text { seofonfeald } \\
\text { manigfeald }\end{array}$ & -fold & threfold & -fold & twofold, manyfold \\
\hline $\begin{array}{l}\text {-full } \\
(<\text { full })\end{array}$ & $\begin{array}{l}\text { sorgfull } \\
\text { synnfull } \\
\text { carful }\end{array}$ & -ful(l) & $\begin{array}{l}\text { synneful, } \\
\text { sunneful, } \\
\text { careful }\end{array}$ & -ful & $\begin{array}{l}\text { sinful, } \\
\text { careful }\end{array}$ \\
\hline $\begin{array}{l}\text {-lēas } \\
(<\text { lēas })\end{array}$ & $\begin{array}{l}\text { slōplēas } \\
\text { reccelēas }\end{array}$ & -lees & $\begin{array}{l}\text { sleeplees, } \\
\text { waterlees }\end{array}$ & -less & $\begin{array}{c}\text { sleepless, reckless, } \\
\text { waterless }\end{array}$ \\
\hline$-\operatorname{lic}(<l \bar{i} c)$ & $\begin{array}{c}\text { frēondlic } \\
\text { dēadlic } \\
\text { gēarlic, luflic }\end{array}$ & $-1 y$ & $\begin{array}{l}\text { dedly, } \\
\text { hoomly, } \\
\text { yearly }\end{array}$ & $-\mathbf{l y}$ & $\begin{array}{c}\text { friendly } \\
\text { deadly, lovely, homely }\end{array}$ \\
\hline -weard & $\begin{array}{l}\text { hāmweard } \\
\text { inneweard }\end{array}$ & -ward & hoomeward & -ward & $\begin{array}{l}\text { homeward, } \\
\text { southward }\end{array}$ \\
\hline & & $\begin{array}{l}\text {-able/ } \\
\text {-ible }\end{array}$ & $\begin{array}{l}\text { admirable } \\
\text { flexible }\end{array}$ & $\begin{array}{l}\text {-able/ } \\
\text {-ible }\end{array}$ & admirable, flexible \\
\hline & & -ous & $\begin{array}{l}\text { curious, thunder- } \\
\text { ous }\end{array}$ & -ous & curious \\
\hline & & -ent & indigent & -ent & indigent \\
\hline & & -ate & immediate & -ate & immediate \\
\hline & & -ie & contrarie & -ry & contrary \\
\hline
\end{tabular}

Old English verbs did not have an elaborate system of suffixes. In Middle English it was considerably enriched by borrowings.

Word-formation processes have always played a significant role in the English language. Starting from around the $7^{\text {th }}$ century a great number of new words and concepts connected with Christianity and Christianisation have entered English. An interesting fact is that loans could take Germanic suffixes, as in: preosthad 'priesthood', clerihad, biscophad 'episcopate', cristendom 'Christendom'. Later on the same process is observed with the French root-morphemes secretnesse (found in G. Chaucer), simpleness (W. Shakespeare), and abnormalness (J. Benson). This shows that the receiving system's parameters were rather stable; they modified the incoming words, thus adjusting the latter to the system. In Otto Jespersen's words, it is rather the natural thing for a language to utilise its own resources before drawing on other languages [Jespersen 1905: 48].

A vivid example of the fact that 'in not a few cases, the English soil has proved more fertilising than the French soil from which words were transplanted' [ibidem, 110] is the French noun mutin that has very few derivatives in its native language (only mutineer and mutinerie) but on entering the 
English language it gave birth to quite a number of words, such as: mutine (n), mutine (v), mutinous (adj), mutinously

$(a d v)$, mutinousness (n), mutiny (n), mutiny (v), mutineer (n), mutineer (v), mutinise ( $v)$.

Table 3. Changes in the subsystem of verb-forming suffixes

\begin{tabular}{|c|c|c|c|c|c|}
\hline \multicolumn{2}{|c|}{ Old English } & \multicolumn{2}{c|}{ Middle English } & \multicolumn{2}{c|}{ Modern English } \\
\hline suffix & examples & suffix & examples & suffix & examples \\
\hline -sian & $\begin{array}{c}\text { clōensian, } \\
\text { bletsian }\end{array}$ & -sen & blessen & - & \\
\hline -läean & nēalöecan & -lechen & nehlechen & - & \\
\hline -ettan & $\begin{array}{c}\text { bliccettan, coh- } \\
\text { hettan }\end{array}$ & -etten & & - & \\
\hline & & -ish & astonish,admonish & -ish & astonish \\
\hline & & -er & render, surrender & -er & surrender \\
\hline & & -fy & scarify, tipsify & -(i)fy & justify \\
\hline & & & & -en & widen \\
\hline & & & & -ise/-ize & popularise \\
\hline & & & & -ate & chlorinate \\
\hline
\end{tabular}

Table 4. Changes in the subsystem of English prefixes

\begin{tabular}{|c|c|c|c|c|c|}
\hline \multicolumn{2}{|r|}{ Old English } & \multicolumn{2}{|c|}{ Middle English } & \multicolumn{2}{|c|}{ Modern English } \\
\hline prefix & examples & prefix & examples & prefix & examples \\
\hline$\overline{\mathbf{a}}-$ ('away') & $\begin{array}{l}\bar{a} \text {-rīsan 'arise', } \\
\bar{a} \text {-bycgan 'compensate for', } \bar{a} \text {-bittan 'bite' }\end{array}$ & a- & $\begin{array}{l}\text { abuggen, arisen, } \\
\text { abiten }\end{array}$ & - & \\
\hline$\overline{\mathbf{a}} \mathbf{g}-$ (generalisation) & $\begin{array}{l}\overline{\bar{e} g} \text {-hwā 'all', } \\
\overline{\alpha e} g-h w \bar{e} r \text { 'everywhere', }\end{array}$ & ay-, ei- & either & - & \\
\hline $\begin{array}{c}\text { be- } \\
\text { ('about', 'around') }\end{array}$ & $\begin{array}{l}\text { be-rīdan 'ride round', } \\
\text { begān 'go round', } \\
\text { be-cuman }\end{array}$ & $\begin{array}{l}\text { be- } \\
\text { bi- }\end{array}$ & $\begin{array}{l}\text { bicomen, } \\
\text { bisetten }\end{array}$ & - & $\begin{array}{l}\text { become } \\
\text { beset }\end{array}$ \\
\hline be- (deprivative) & $\begin{array}{l}\text { be-dōean 'deprive', } \\
\text { be-héafdian 'behead' }\end{array}$ & $\begin{array}{l}\text { be- } \\
\text { bi- }\end{array}$ & $\begin{array}{l}\text { bifallen, } \\
\text { bihelden }\end{array}$ & - & $\begin{array}{l}\text { befall, } \\
\text { behold }\end{array}$ \\
\hline for- (intensifier) & $\begin{array}{l}\text { for-boernan 'burn up', } \\
\text { for-bēodan }\end{array}$ & for- & for-beden & - & forbid \\
\hline \begin{tabular}{|c|} 
ge- \\
(a perfective sense)
\end{tabular} & $\begin{array}{l}\text { ge-äscian 'find out', } \\
\text { ge-weald 'power' } \\
\text { ge-writ 'write' }\end{array}$ & $\begin{array}{l}\mathbf{i}- \\
\mathbf{y}-\end{array}$ & $\begin{array}{l}\text { iwold, iweld, } \\
i \text {-writ }\end{array}$ & - & \\
\hline $\begin{array}{c}\text { mis- } \\
\text { (negative) }\end{array}$ & $\begin{array}{l}\text { mis-bēodan, } \\
\text { mis-dōn 'do ill' }\end{array}$ & mys- & $\begin{array}{l}\text { mys-beden, } \\
\text { mys-doon }\end{array}$ & mis- & \\
\hline $\begin{array}{c}\text { of- } \\
\text { (intensifier) }\end{array}$ & $\begin{array}{l}\text { of-slēan 'kill', } \\
\text { of-tēon 'take away' }\end{array}$ & of- & $\begin{array}{l}\text { of-sleen, } \\
\text { of-slayen }\end{array}$ & - & \\
\hline ofer- (over-) & ofer-cuman 'overcome' & over- & over-comen & over- & overcome \\
\hline $\begin{array}{l}\text { on-, an- } \\
\text { (negative) }\end{array}$ & $\begin{array}{l}\text { on-bindan 'unbind', } \\
\text { on-lūcan 'unlock' }\end{array}$ & - & & - & \\
\hline $\begin{array}{c}\text { or- } \\
\text { (deprivative) }\end{array}$ & $\begin{array}{l}\text { or-mōd 'without courage', } \\
\text { or-sorg 'careless' }\end{array}$ & - & & - & \\
\hline $\begin{array}{c}\text { or- } \\
\text { (early, original, } \\
\text { beginning) }\end{array}$ & $\begin{array}{l}\text { or-eald 'of great age', } \\
\text { or-Panc 'inborn thought, ingenuity, skill' }\end{array}$ & - & & - & \\
\hline $\begin{array}{c}\text { t̄̄o- } \\
\text { (separation) }\end{array}$ & $\begin{array}{l}\text { tō-faran v.i. 'go apart', } \\
\text { tō-brecan 'break into pieces' }\end{array}$ & to- & $\begin{array}{l}\text { tofaren, } \\
\text { tocume, tocome, } \\
\text { tobreken }\end{array}$ & - & \\
\hline $\begin{array}{c}\text { un- } \\
\text { (negative) }\end{array}$ & $\begin{array}{l}\text { un-gecnāwen, } \\
\text { un-hold 'unfriendly' }\end{array}$ & un- & unknowen & un- & unknown \\
\hline $\begin{array}{c}\text { un- } \\
\text { (pejorative) }\end{array}$ & $\begin{array}{l}\text { un-giefu 'evil gift', } \\
\text { un-dcéd 'bad deed' }\end{array}$ & un- & & & \\
\hline $\begin{array}{c}\text { wan- } \\
\text { (deprivative, nega- } \\
\text { tive) } \\
\end{array}$ & $\begin{array}{l}\text { wan-häl 'not hale, ill', } \\
\text { wan-hoga 'thoughtless man' }\end{array}$ & - & & - & \\
\hline $\begin{array}{c}\text { wip- } \\
\text { ('against') }\end{array}$ & $\begin{array}{l}\text { wiP-cèosan 'reject', } \\
\text { wiP-cwePan 'contradict', } \\
\text { wiP-feohtend 'enemy' }\end{array}$ & with- & & with- & withdraw \\
\hline \multirow[t]{3}{*}{$\begin{array}{c}\text { ymb- } \\
\text { ('around') }\end{array}$} & $\begin{array}{l}\text { ymb-gang 'circuit, circumference', } \\
\text { ymb-lódan 'lead round' }\end{array}$ & - & & - & \\
\hline & & $\begin{array}{l}\text { dis-/ } \\
\text { des- }\end{array}$ & $\begin{array}{l}\text { disappoint, } \\
\text { distrust }\end{array}$ & $\begin{array}{l}\text { dis-/ } \\
\text { des- }\end{array}$ & \\
\hline & & en- & $\begin{array}{l}\text { encage, } \\
\text { encircle }\end{array}$ & $\begin{array}{l}\text { en-/ } \\
\text { em- }\end{array}$ & $\begin{array}{c}\text { encircle, } \\
\text { embed }\end{array}$ \\
\hline
\end{tabular}

Prefixes. In Old English, prefixes were used with various word classes to:

- stress the meaning of the base of the word, as in: Sume wig fornōm [The Wanderer, line 80] / lit.: some-ACC/ war /took away/ - 'War destroyed several'. (OE niman 'take', OE forniman 'take away'). 
- show negation, e.g. and sćde him unforht, 'Witodlīce

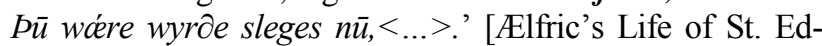
mund, line 189] - 'and said to him unafraid, 'Certainly you were worthy of death now', <..>'.

- mark the grammatical category of aspect of the verbs, as in: AEfter Dysum wordum hē gewende tō Dām cerendracan $<$...> [Ælfric's Life of St. Edmund, line 188] - 'after these words he returned to that messenger $<\ldots>$ '.

However, most of the Old English prefixes lost their productivity and gradually went out of use in later periods, while some others appeared to be employed in the process of word formation (see Table 4). This proves a dynamic character of the subsystem of affixation in the English language.In Modern English, there are far more prefixes than in Old English or in Middle English. Moreover, many of the original Germanic prefixes were lost. In the late $10^{\text {th }}$ century, the subsystem of prefixes underwent desingression as a result of the weakening of the meaning of prefixes and their chaotic usage. Weakening of the subsystem of prefixes made it vulnerable to foreign influence; it thus changed the degree of anisotropy of the given part of the language megasystem and, in fact, prepared the ground for new elements that began to appear in usage in the late $11^{\text {th }}$ century.

Most prefixes used in Modern English are of Latin or Greek origin. Among them: anti-, pro-, contra-, counter-; non-, circum-, extra-, fore-, inter-, intra-, mid-, out-, over, sub-, super-, tele-, trans-, under-; macro-, mega-, micro-, hyper-, hypo-; ante-, ex-, neo-, post-, pre-, re-; mono-, uni-, poly-, multi-, semi-, bi-, di-, to mention just a few. They can be grouped semantically - into locative, temporal, quantitative, negative, those indicating size, etc.

The origin of prefixes is also essential. Table 4 above shows the adverbial or prepositional semantics of certain prefixes in Old English. Obviously, prefix-contained lexemes were originally compound (two-stemmed) words. Let us assume that in the course of time it was a stress shift within a compound word that brought about the blending of the two stems into one word in which the second component was reinterpreted as a root morpheme while the first component compressed to an affix preceding it (hence the term 'prefix' meaning 'coming before, preceding'). Thus, it is possible to conclude that the form of a word is not a limited symmetrical unity but an evolving dynamic integrity. This proves a fractal principle of word-formation in English.

Conclusions. On the whole, the word-formation subsystem of the English language reveals features of a synergetic system, since it is open, dynamic and fractally-organised. When 'unpacking' a (today) simple word, studying its inner structure, unveiling the ways of its 'birth', we may find out that it is of a complex organisation and includes in itself formerly independent words, now transformed into supporting instruments (prefixes, suffixes, connecting elements, etc.) of word-formation processes.

Synergetics has offered powerful research equipment for science and the humanities. It is seen as a conceptualmethodological basis for interdisciplinary synthesis of knowledge, a sort of bridge between various spheres of scientific activity. New discoveries still lie ahead..

\section{REFERENCES}

1. Dombrovan, Tetiana. (2012) Linguistic Synergetics: A hopeful look towards future // European Science and Technology: $3^{\text {rd }} \mathrm{In}-$ ternational research and practice conference (Munich, 30-31 October, 2012). Vol. II. Publ. Office Vela Verlag Waldkraiburg. Munich, Germany. - pp. 116-118.

2. Haken, Hermann (1977). Synergetics. An Introduction. (Springer Series in Synergetics) - Berlin: Springer-Verlag.

3. Jespersen, Otto. Growth and Structure of the English Language. Leipzig: Teubner, 1905. $-274 \mathrm{p}$.

4. Kastovsky, Dieter (2005). Semantics and vocabulary. In: The

Cambridge History of the English language, Vol.1. The Beginnings to 1066. Edited by Richard M. Hogg. Cambridge: Cambridge University Press. - pp. 290- 408.

5. Mitchell, Bruce, and Fred C.Robinson (1997). A Guide to Old English. $5^{\text {th }}$ ed. Oxford: Blackwell Publishers Ltd.

6. Smirnitckii A.I. (1998). Drevneangliiskii iazyk. - M.: MGU imeni M.V.Lomonosova. (In Russian).

7. Taranetc V.G. (2009). Tripilskii substrat: Pokhodzhennia davno€vropeiskikh mov. - Odesa: ORIDU NADU. (In Ukrainian).

\section{SOURCES}

1. Flfric's Life of St.Edmund. In: Mitchell, Bruce, and Fred C. Robinson. A Guide to Old English. $5^{\text {th }}$ ed. Oxford: Blackwell Publishers Ltd., 1997. - pp. 195-203.

2. Bede's Account of the Poet Cædmon. In: Mitchell, Bruce, and Fred C. Robinson. A Guide to Old English. $5^{\text {th }}$ ed. Oxford: Blackwell Publishers Ltd., 1997. - pp. 220-225.

3. Beowulf [Electronic resource]. Mode of access: http://www.fordham.edu/halsall/basis/Beowulf-oe.asp

4. Beowulf: A Verse Translation (by Seamus Heaney). Edited by

Daniel Donoghue. - New York: W.W. Norton \& Co. Inc., 2002. $-256 \mathrm{p}$.

5. British National Corpus [Electronic resource]. Mode of access: http://www.natcorp.ox.ac.uk

6. The York-(Toronto)-Helsinki Parsed Corpus of Old English Prose / Taylor, A., A. Warner, S. Pintzuk, and F. Beths. 2003. Project home page: http://wwwusers.york.ac.uk/ lang22/YCOE/YcoeHome.htm(YCOE).

\section{Диахроническая лингвосинергетика: в фокусе - простые и производные слова}

\section{Т. И. Домброван}

Аннотация. В статье предпринята попытка рассмотреть морфологическую структуру слов английского языка с позиций новой научной парадигмы, которую представляет синергетика. Методологическая особенность синергетики заключается в изучении процессов эволюции как многоступенчатой самоорганизации определенного структурного единства. Язык определяется как синергетическая система благодаря таким его основным характеристикам, как открытость, нелинейность, динамичность и фрактальность организации. Словообразовательная система в целом и, в частности, подсистема аффиксов как функциональных единиц для образования новых слов, также представляет собой синергетическую систему, поскольку обладает характеристиками таковой и подвержена изменениям под влиянием внешних факторов, воздействующих на языковую систему.

Ключевые слова: синергетика, диахроническая синергетика, синергетическая система, язык, структура слова, английский язык. 